\title{
First records of Paspalum notatum Flüggé and $P$. urvillei Steud. (Poaceae) in Korea
}

\author{
Jeongran Lee, Chang-Seok Kim*, In-Yong Lee and Young-Woo Han \\ National Academy of Agricultural Science, Suwon 441-701, Korea \\ *Correspondent: e-mail: rdacskim@korea.kr
}

\begin{abstract}
While collecting Poaceae weeds at Jeju-do, we found two unrecorded species of the Paspalum, P. notatum Flüggé and P. urvillei Steud. We provide the descriptions and illustrations of both species. Key to the newly recorded species and related taxa of Korean Paspalum is also presented.
\end{abstract}

Keywords: Paspalum notatum, Paspalum urvillei, Poaceae, unrecorded species

(C) 2013 National Institute of Biological Resources

DOI: 10.12651/JSR.2013.2.1.079

\section{INTRODUCTION}

Poaceae Barnhart, the fourth largest plant family after the Asteraceae, Fabaceae, and Orchidaceae, includes approximately 700 genera and 11,000 species in all regions of the world (Chen and Phillips, 2006). Its economic importance is enormous because it provides the main cereal crops such as Triticum, Oryza, Zea, Hordeum etc. Poaceae are distributed throughout Korea with about 96 genera and 252 taxa (Korea National Arboretum, 2011).

The geuns Paspalum L. is composed of approximately 330 species growing in the Americas, in the tropical, subtropical, and warm-temperate areas (Chen and Phillips, 2006). Because of their utilities as turf, forage, and erosion control, many taxa including $P$. notatum are now widely distributed and have become some of the world's most troublesome weeds (Holm et al., 1979).

Paspalum species are recognized by their plano-convex abaxial spikelets, often with a ovate, orbicular, elliptic or oblong shape, the upper lemma oriented towards the rachis and the lower glume typically being absent (Renvoize, 1995; Clayton and Renvoize, 1999; Riefner and Denham, 2010). Only four taxa, $P$. thunbergii Kunth ex Steud., P. dilatatum Poir., P. distichum L. var. distichum, and var. indutum Shinners, have been reported in Korea (Ryang, 2004; Lee, 2007; Korea National Arboretum, 2007; 2011). Paspalum distichum var. distichum and var. indutum are found at the wetlands or watercourses of southern provinces, western and southern coast, and Jejudo, respectively, while $P$. thunbergii has nationwide distribution. Paspalum dilatatum is expanding its distribution range after the naturalization at Jeju-do (Kang, 2008).
Recently, we found two unrecorded species of Paspalum, $P$. notatum Flüggé and $P$. urvillei Steud., at Jeju-do in Korea. Here, both of the newly recorded species are described and illustrated. We also provide a taxonomic key to the species of Paspalum in Korea.

\section{Materials and Methods}

The two species were collected at Gangjeong-dong and Beophwan-dong of Seogwipo-si, Jeju-do in August and September 2011. Original descriptions of both species were checked (Flüggé, 1810; Steudel, 1855) and their habits and spikelets are photographed (Fig. 1) and drawn (Figs. 2 and 3).

Nomenclature of Paspalum followed Clayton et al. (2012). All the voucher specimens are deposited at the Herbarium Culture Collection at National Academy of Agricultural Science, Suwon, Korea (HCCN).

\section{DesCriPTIONS AND Discussion}

\section{Paspalum notatum Flüggé, Gram. Monogr., Paspalum 106. 1810.}

Paspalum taphrophyllum Steud., Syn. Pl. Glumac. 1: 19 (1853).

Paspalum distachyon Willd. ex Döll in C.F.P.von Martius \& auct. suc. (eds.), Fl. Bras. 2(2): 73 (1877), pro syn.

Paspalum saltense Arechav., Anales Mus. Nac. Montevideo 1: 53 (1894).

Paspalum uruguayense Arechav., Anales Mus. Nac. Montevideo 1: 54 (1894). 

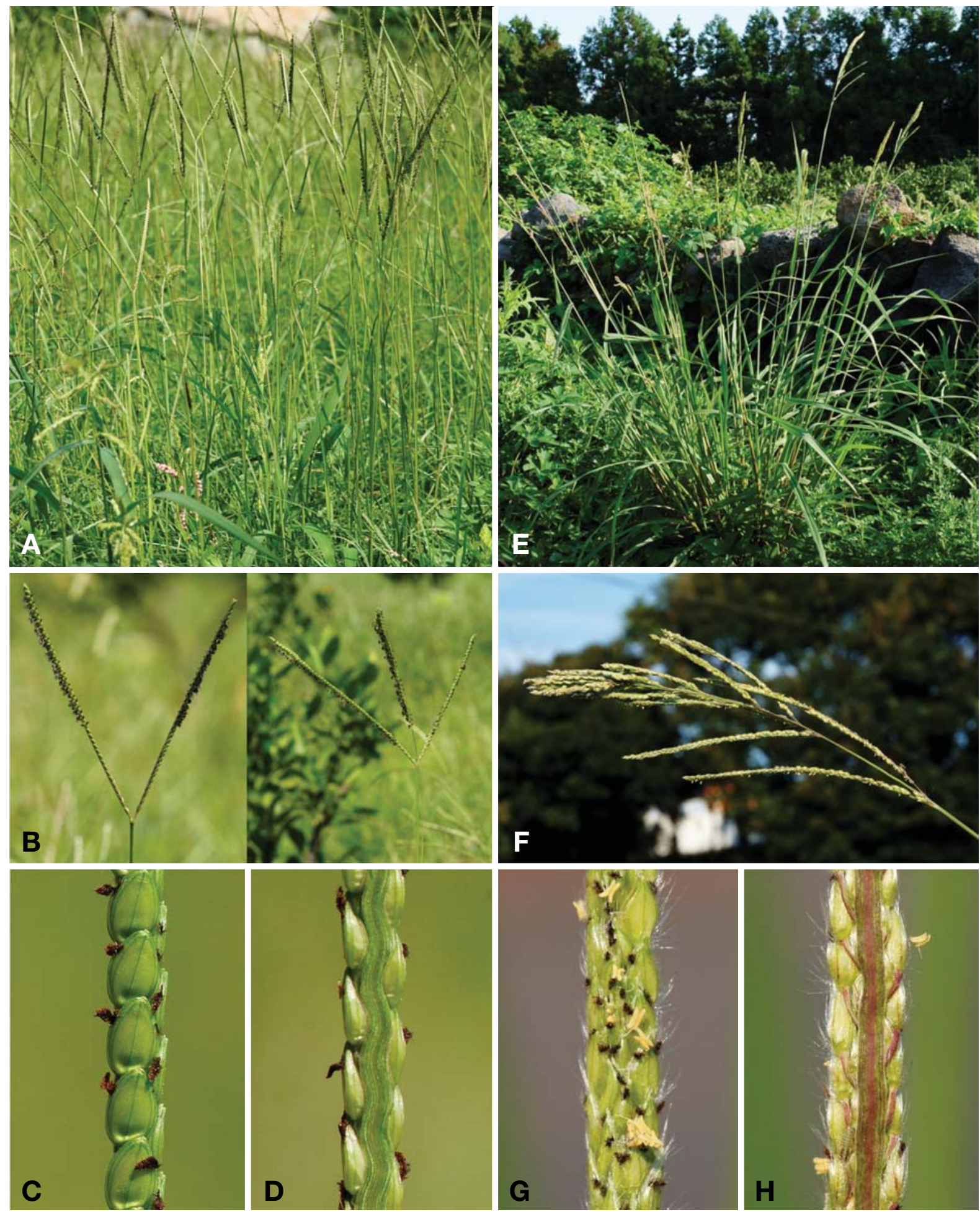

Fig. 1. Paspalum notatum (A-D) and P. urvillei (E-H). A, E. habits. B, F. inflorescences. C, D, G, H. Portions of the inflorescences. C, G. abaxial side. D, H. adaxial side.

Common name: Bahiagrass, Bahia grass (Allen and Hall, 2007; Osada, 1989).

Korean name: Min-Doong- Cham-sae-pee (민둥참새피)
Perennial with stout, scaly rhizomes. Culms $15-110 \mathrm{~cm}$ tall. Leaf sheaths compressed, keeled, glabrous; leaf blades narrowly linear, flat or folded, stiffly spreading, 5- 
$30 \mathrm{~cm}$ long, 2-10 $\mathrm{mm}$ wide, glabrous; ligule less than 1.5 $\mathrm{mm}$. Inflorescence a digitate pair of racemes, rarely 3; racemes 10-13 (-16) cm long, recurved-ascending; spikelets single, in 2 row; rachis 1-1.8 mm wide, scabrous. Spikelets green, ovate to obovate, plano-convex, 2.5-4.0 mm long, 1.7-2.5 mm wide, smooth, shining, obtuse; lower glumes absent, upper glume cartilaginous, 3(-5)-veined, glabrous; lower lemma resembling upper glume but slightly shorter; upper lemma pale green to light yellow; palea coriaceous, shiny.

Habitats. In inhabited area, at the edges of forests.

Distribution. Native to Mexico through the Caribbean and Central America to Brazil, northern Argentina, U.S.A., Australia (USDA, ARS, National Genetic Resources Program, 2012), Japan (Osada, 1989), China (Chen and Phillips, 2006).

Specimens examined. Korea. Jeju-do: 897 Gangjeongdong, Seogwipo-si, N $33^{\circ} 15^{\prime} 40.82^{\prime \prime}$, E $126^{\circ} 29^{\prime} 20.19^{\prime \prime}$, 15 Sept. 2011. C. S. Kim \& J. Lee. Kim 201109-01 05 (HCCN, 5 sheets).

Paspalum notatum is notable for its prominent dual, $\mathrm{V}$-shaped inflorescence consisting of two (rarely three) spike-like racemes containing multiple tiny spikelets, each about 2.5-4.0 $\mathrm{mm}$ long and 1.7-2.5 mm wide (Fig. 2 ). The margins of the upper glume and lower lemma are smooth and can be distinguished from $P$. distichum by having an entirely smooth upper glume. This species is native to Central America and introduced to the United States for forage, turf, and erosion control (Allen and Hall, 2007). In Asia, it is also found in Japan, China, and Taiwan. The time of introduction to Jeju-do is not clear. But it was quite predominant with $P$. dilatatum at the inhabited areas of Gangjeong-dong, Seogwipo-si and found at the several orchards in Jeju-do. The Korean name is given as 'Min-Doong-Cham-Sae-Pee' based on the characteristics of glabrous spikelets. Although many species of Paspalum are grown as a grain, forages and turf, most of the species are weeds (Häfliger and Scholz, 1982). It is possible that $P$. notatum could be one of major weeds in Jeju-do because of its persistent nature that does not allow native species to survive.

\section{Paspalum urvillei Steud., Syn. Pl. Glumac. 1: 24.}

1853.

Paspalum ovatum var. parviflorum Nees in C.F.P.von Martius, Fl. Bras. Enum. Pl. 2: 43 (1829).

Paspalum velutinum Trin. ex Nees in C.F.P.von Martius, Fl. Bras. Enum. Pl. 2: 43 (1829), pro syn.

Paspalum dilatatum var. parviflorum Döll in C.F.P.von Martius \& auct. suc. (eds.), Fl. Bras. 2(2): 64 (1877).

Paspalum virgatum var. parviflorum Döll in C.F.P.von Martius \& auct. suc. (eds.), Fl. Bras. 2(2): 89 (1877).

Paspalum larranagae Arechav., Anales Mus. Nac. Montevideo 1: 68 (1894).
Paspalum vaseyanum Scribn., Bull. Div. Agrostol. U.S. D.A. 17: 32 (1899).

Paspalum griseum Hack. ex Corrêa, Fl. Braz.: 128 (1909), nom. nud. (Clayton et al., 2012).

Common name: Vaseygrass, Vasey grass (Osada, 1989; Allen and Hall, 2007).

Korean name: Tul-Keun-Cham-sae-pee (털큰참새피)

Perennial with a short (less than $1 \mathrm{~cm}$ ) rhizomes. Culms densely tufted, robust, up to $220 \mathrm{~cm}$ tall, glabrous. Lower sheaths pubscent, upper sheaths glabrous; leaf blades linear, 12-60 cm long, 0.2-1.5 cm wide, mostly glabrous, a few long hairs at the base, apex attenuate; ligule membranous, $3-5 \mathrm{~mm}$. Inflorescence axis $10-30 \mathrm{~cm}$; a panicle consisted of 10-30 racemes; racemes $8-15 \mathrm{~cm}$, narrowly ascending or suberect; spikelets paired; rachis ca. 0.5-1.1 $\mathrm{mm}$ wide. Spikelets light green or purplish, ovate, 1.8-2.8 $\mathrm{mm}$ long, 1.2-1.7 mm wide, sharply acute; upper glume membranous, 3-veined with laterals marginal, appressed pubescent on back, margins densely fringed with long white hairs; lower lemma similar to upper glumes but glabrous on back; upper lemma elliptic, striate, obtuse; palea 1.6-2.1 mm long.

Habitats. In moist, open, disturbed areas and roadsides. Distribution. China, Hong Kong, Taiwan (Chen and Phillips, 2006), Japan (Osada, 1989), U.S.A., Bolivia, Argentina, Chile, Paraguay, Uruguay (Allen and Hall, 2007; USDA, ARS, National Genetic Resources Program, 2012).

Specimens examined. Korea. Jeju-do: 1289-4 Beophwandong, Seogwipo-si, N $33^{\circ} 14^{\prime} 11.28^{\prime \prime}$, E $126^{\circ} 30^{\prime} 30.64^{\prime \prime}$, 30 Aug. 2011. C.S. Kim and J. Lee. Kim 201108-01 02 (HCCN, 2 sheets).

Paspalum urvillei is native to South America and widespread in tropical to warm-temperate regions of the world as a forage grass and weed (Osada, 1989; Chen and Phillips, 2006). It was first found at Beophwan-dong, Seogwipo-si. Although the number of individuals of this species in a single area was rarely found they were distributed in a large area along the roadside. Paspalum urvillei is similar to $P$. dilatatum because both species have long hairs on their margins of spikelets. They are, however, different in that $P$. urvillei has relatively small flower spikelets (1.8-2.8 $\mathrm{mm}$ long) compared to those (2.7-4.1 $\mathrm{mm}$ long) of $P$. dilatatum; $P$. urvillei has $10-30$ racemes while $P$. dilatatum has 2-7 (Queensland Government, 2012). This species also could be a noxious weed in Jejudo because it has already been regarded as one of noxious weeds in many countries including Australia and the United States especially in Hawaii (Pacific Islands Ecosystems at Risk, 2008; FloraBase, 2012). The Korean name, 'Tul-Keun- Cham-Sae-Pee' reflects that the plants have many hairs on the leaf sheaths and spikelets and are similar to P. dilatatum (Keun-Cham-Sae-Pee). 


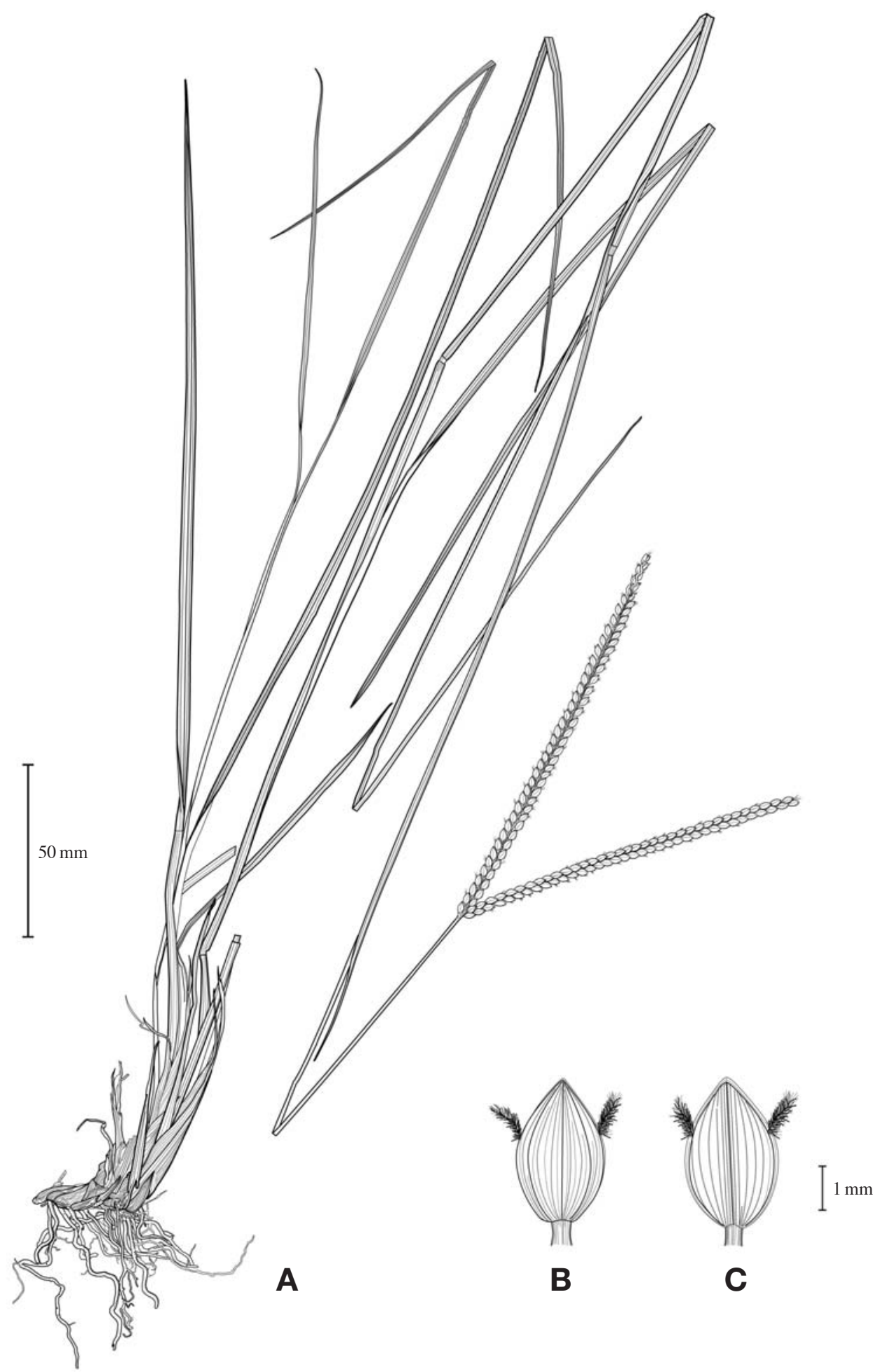

Fig. 2. Paspalum notatum Flüggé. A. habit; B, C. spikelet. B. abaxial side. C. adaxial side.

A Key to Paspalum in Korea

1. Spikelets with a marginal ciliate fringe of silky hairs; hairs $1-2 \mathrm{~mm}$.

2. Racemes 2-7; spikelets 3-4 mm long
P. dilatatum

2. Racemes 10-30; spikelets 2-3 mm long P. urvillei

1. Spikelets glabrous or pubescent, without a marginal 


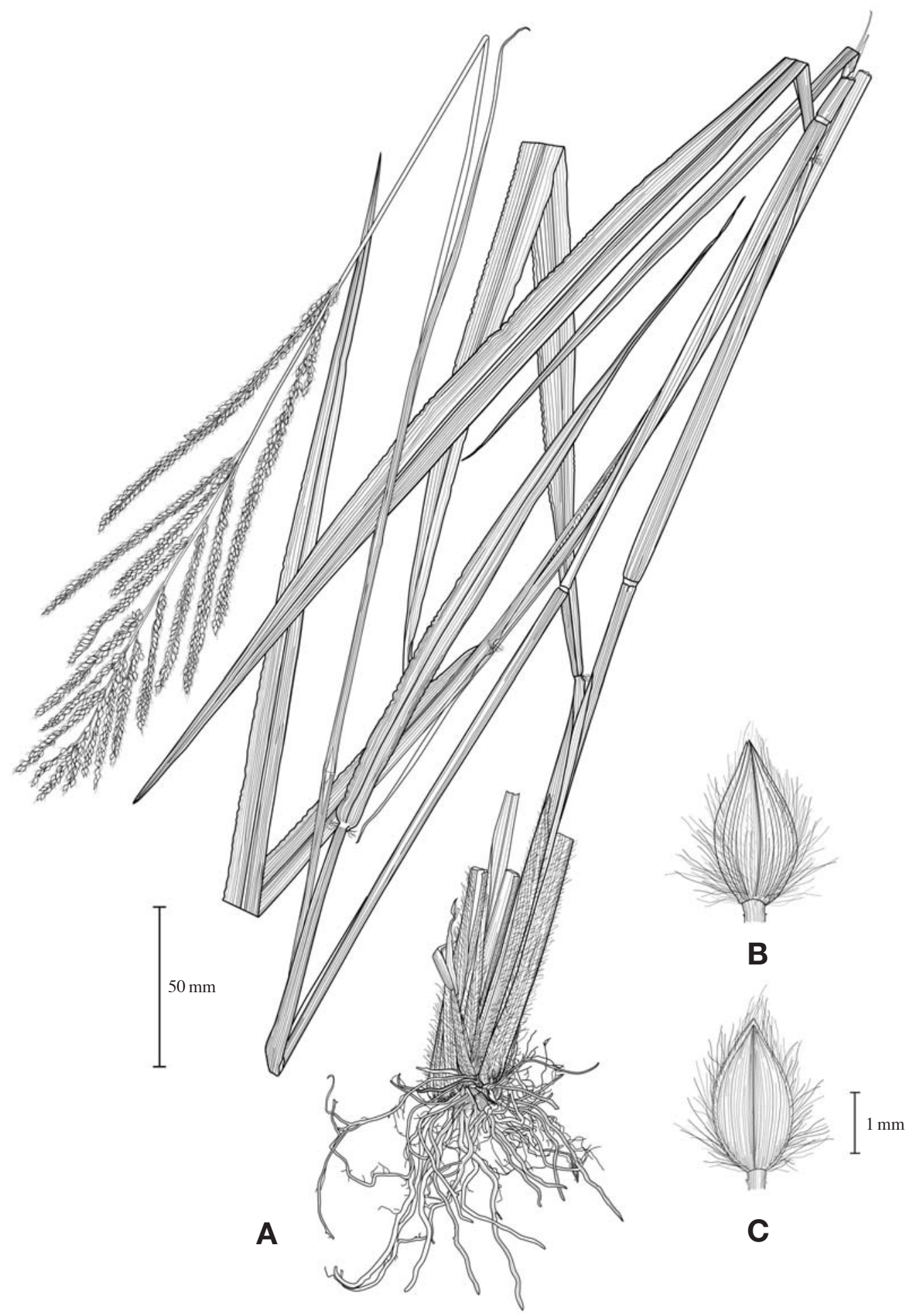

Fig. 3. Paspalum urvillei Steud. A. habit; B, C. spikelet. B. abaxial side. C. adaxial side.

fringe of silky hairs.

3 . Plants with long stolons and/or rhizomes; racemes $2(-3)$, paired; spikelets born singly.

4. Plant with robust rhizomes; upper glume and lower lemma cartilaginous and shiny, obtuse P. notatum

4. Plant with slender stolons; upper glume and lower lemma papery, acute. 
5. Racemes 2; leaf sheath and nodes often glabrous ….... P. distichum var. distichum

5. Raceme 2 or 3; leaf sheath and nodes often pubescent

$P$. distichum var. indutum

3. Plants tufted; racemes 3-5 along a common axis, spikelets commonly paired ……... P. thunbergii

\section{ACKNOWLedgements}

This research was supported by the project from the Cooperative Research Program for Agricultural Science \& Technology Development (Project No. PJ008548) of RDA. We appreciate the contributions of three anonymous reviewers for helpful comments, corrections and suggestions on the earlier draft of this manuscript.

\section{REFERENCES}

Allen, C.M. and D.W. Hall. 2007. Paspalum L. In Flora of North America, North of Mexico. Vol. 25. In: M.E. Barkworth, K.M. Capels, S. Long and M.B. Piep (eds.), Oxford University Press, New York Oxford. pp. 566-600.

Chen, S. and S.M. Phillips. 2006. Poaceae (Gramineae). In Flora of China, Vol. 22. Wu, Z.Y., P.H. Raven and D.Y. Hong (eds.), Science Press and Missouri Botanical Garden Press, Beijing and St. Louis. Pp. 526-531.

Clayton, W.D. and S.A. Renvoize. 1999. Genera Graminum. Grasses of the world. Kew Bulletin additional sereies XIII. Royal Botanic Gardens, Kew. pp. 287-288.

Clayton, W.D., R. Govaerts, K.T. Harman, H. Williamson and M. Vorontsova. 2012. World Checklist of Poaceae. Royal Botanic Gardens, Kew [Available from: http://apps. kew.org/wcsp/synonomy/accessed 13 December 2012].

FloraBase. 2012. The Western Australian Flora. Western Australian Herbarium, Department of Environment and Conservation [Available from: http://florabase.dec.wa. gov.au/browse/profile/532/, accessed 13 December 2012].

Flüggé, A.D.J. 1810. Graminum monographiae. Pars I. Paspalus. Reimaria. impensis F. Perthes et J.H. Besser in Hamburgi.

Häfliger, E. and H. Scholz. 1982. Grass Weeds: Weeds of the subfamily Panicoideae. Documenta Ciba-Geigy, Basle, Switzerland. pp. 91-109.

Holm, L., J.V. Pancho, J.P. Herberger and D.L. Plucknett.
1979. A. geographical atlas of world weeds. John Wiley \& Sons, New York.

Kang, B.H. 2008. An illustrated ecology books of Korean medicinal plant resources. III. Geobook, Seoul. pp. 188-191 (in Korean).

Korea National Arboretum. 2007. A Synonymic List of Vascular Plants in Korea. Pocheon, Gyeonggi-do. pp. 349350 (in Korean).

Korea National Arboretum. 2011. Illustrated Grasses of Korea (A revised and enlarged edition). Pocheon, Gyeonggi-do. pp. 458-465 (in Korean).

Lee, Y.N. 2007. Poaceae. In The Genera of Vascular Plants of Korea. Flora of Korea Editorial Committee (eds.), Academy Publishing Co. Seoul. pp. 1182-1264.

Osada, T. 1989. Illustrated grasses of Japan. Heibonsha Ltd. Tokyo. pp. 582-595.

Pacific Islands Ecosystems at Risk (PIER). 2008. Paspalum urvillei Steud., Poaceae [Available from: http://www.hear. org/pier/species/paspalum_urvillei.htm/, accessed 13 December 2012].

Queensland Government. 2012. Weeds of Australia. Fact Sheet Index. Biosecurity Queensland Edition [Available from: http://keyserver.lucidcentral.org/weeds/data/03030 800-0b07-490a-8d04-0605030c0f01/media/Html/Index. htm/, accessed 12 December 2012].

Renvoize, S.A. 1995. A New Species of Paspalum (Gramineae) from Bolivia. Kew Bulletin 50(2):339-341.

Riefner, R.E.J. and S.S. Denham. 2010. Paspalum pubiflorun and $P$. quadrifarium (Poaceae), new to California, with a key and notes on invasive species. Journal of the Botanical Research Institute of Texas 4(2):761-770.

Ryang, H.S., D.S. Kim and S.H. Park 2004. Weeds of Korea. III. Monocotyledoneae Pteridophyta. Rijeon Agricultural Resources Publication. Seoul. pp. 512-529 (in Korean).

Steudel, E.G. 1855. Synopsis plantarum glumacearum. Stuttgartlae. J.B. Metyzier. 1:24.

The Plant List. 2010. Version 1 [Available from: http://www. theplantlist.org/, accessed 12 December, 2012].

USDA, ARS, National Genetic Resources Program. 2012. Germplasm Resources Information Network-(GRIN) [Online Database]. National Germplasm Resources Laboratory, Beltsville, Maryland [Available from: http://www. ars-grin.gov/cgi-bin/npgs/html/queries.pl/, accessed 12 December, 2012].

Submitted: January 18, 2013, Accepted: February 15, 2013 